\title{
ЕЛЕМЕНТИ РАЗГОВОРНОГ СТИЛА КАО РЕПРЕЗЕНТИ НАРОДНОГ ЈЕЗИКА У ДРАМАМА ЈОАКИМА ВУЈИЋА
}

\begin{abstract}
У раду ћемо се бавити идентификацијом и анализом различитих елемената разговорног стила у драми Слепи миш Јоакима Вујића из 1809. године. Структурна, структурно-семантичка и прагматска анализа указаће нам на основне моделе увођења народног језика у језик литературе славеносрпског периода, на елементе разговорног стила - говорног језика и супстандардних језичких израза и конструкција.

Кључне речи: разговорни стил, експресивност, ненормираност, форме обраћања, вокатив, оптативне конструкције, славеносрпски језик, народни језик.
\end{abstract}

1. Целокупно дело Јоакима Вујића, његова језичка, конкретно синтаксичка (структурна), али и стилистичка и прагматска анализа предмет су нашег ширег научног интересовања већ дуже време. ${ }^{1}$ Јоаким Вујић је у српској култури остао запамћен као оснивач - отаи српског театра. Међутим, његов стваралачки опус не чине само драмска дела, напротив. Путописи, поезија, аутобиографска и дневничка дела, различити уџбеници и приручници, ауторски или у преводу, чине га једним од најплоднијих стваралаца свога, славеносрпског, времена, и управо том разноврсношћу литерарног израза драгоценим за језичка истраживња епохе.

Свакако, будући да је једна од тема овогодишњег Научног састанка слависта била разговорни језик и српски књижевни/стандардни језик, језичка анализа управо драмског дискурса Вујићевог дела намеће се као логичан одабир. Раније смо истакли да „драмски текст представља дискурс најпри-

\footnotetext{
*t.matic@yahoo.com

${ }^{1}$ Докторска дисертација са темом Функиије реда речи у делу Јоакима Вујића, прихваћеном на седници Наставно-научног већа Филолошког факултета у Београду, јануара 2017. године.
} 
ближнији разговорном језику, језику свакодневне и уобичајене комуникације. Наиме, реализован кроз дијалошку форму и размену реплика између драмских субјеката, он управо репликама (и додатно дидаскалијама), које су зависно од осмишљености драмског текста у мањој или већој мери артифицијелне, углавном верно осликава и преноси све доминантне особине разговорног функционалног стила, од језичке економије с једне до редунданције

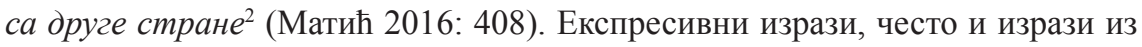
тзв. нижег регистра (вулгаризми, пејоративни изрази, клетве и псовке), затим колокације, паремије и фразеолошки изрази (у ширем смислу) представљају неке од заједничких експликација разговорног функционалног стила (РФС) и драмског регистра као дела књижевноуметничког функционалног стила.

Вујић је аутор великог броја драмских текстова, најчешће комедија, али и историјских и дидактичких драма. Најраније објављене драме су Фернандо и Ярыка и Любовная зависть чрезъ едне иілеле из 1805. године, а последња објављена је драма Сербска принцеза Анђелія из 1837. године. Један део драма је штампан, што за Вујићева живота, што до данас, док се део чува само у рукопису. Велики број рукописа Вујићевих драма је, нажалост, изгорео у бомбардовању Народне библиотеке Србије 6. априла 1941. Највећи број драма јесу „посрбљени” или вернакуларизовани преводи драма познатих, најчешће немачких драмских писаца Вујићева времена. За већину постоје подаци о аутору, години објављивања па и првом извођењу, док за остатак то није утврђено. То нам оставља могућност да неке од њих посматрамо и као оригиналана Вујићева књижевна дела.

Предмет анализе у нашем раду биће грађа ексцерпирана из драме Слепый мышъ, објављене 1809. године, која представља посрбљени превод немачког текста Die Fledermaus из 1802. (Karl Friedrich Hensler). ${ }^{3}$ То је једночинка или како каже аутор у поднаслову весела игра у едномъ дъйствію. ${ }^{4}$

2. Говорећи о језичким варијететима насталим према медијуму остварења, Д. Кликовац једно поглавље посвећује дистинкцијама између појмова разговорни језик и разговорни стил (2008: 173-176.), где предочава терминолошку испреплетаност како у домаћој, тако и у страној лингвистичкој литератури. Разговорни језик и разговорни стил се не могу разликовати јер и један и други термин представљају језик неформалне комуникације, спонтане разговоре, са одабиром лексике и других језичких средстава из укупног, општег језичког фонда. „Стога се једина могућа дистинкција између ових варијетета тиче њихове нормативности" (2008: 174), где би РФС у основи био нормативан, а разговорни језик и стандардан и супстандрадан. Ипак, каже се да је то могуће само ако се „жели поставити оштра граница између стандард-

${ }^{2}$ B. Тошовић 2002: 392

${ }^{3}$ (http://digital.bms.rs/ebiblioteka/pageFlip/reader/index.php?type=publications\&id=1299\&m=2\# page/5/mode/1up) Грађу за рад ексцерпирали смо из оригиналног текста драме, дигитализованог и похрањеног у изузетно богатој и вредној бази Дигиталне библиотеке Матице српске.

${ }^{4}$ Године 1968. је у продукцији Радио телевизије Београд снимљен и филм који се базира на Вујићевој драми, у режији Јована Коњовића, с Карлом Булићем, Радом Ђуричин и Капиталином Ерић у насловним улогама. 
них и нестандардних видова језика свакодневне комуникације - што би било у великој мери вештачки" (Исто: 174).

Ако бисмо од двадесет основних особина разговорног функционалног стила које Б. Тошовић издваја у монографији Функциионални стилови (2002: 383-384) истакли доминантне и најпрепознатљивије, то би свакако биле експресивност и ненормираност. Вујићев уметнички израз, а најчешће и сам модел/механизам постизања комичног, наслања се управо на ове две особине разговорног стила (РС). Ексцерпирана грађа нам на то недвосмислено указује: маторый угурсузе (СМ: 10), маторый магарче (СМ: 14), проклета жено и да бы ли кучко бесна (СМ: 30), Аяо, куку леле мени! (СМ: 19), Хрђа васъ попала и силе васъ сапеле! (СМ: 40), Да е зла и пакостна како годъ Баба Луиііферъ пакленогъ (СМ: 9), Една гадна стара девойчура дебела као четворка (CМ: 9), ${ }^{5}$ Стерпънїе е добаръ Кредиторъ, али хрђавъ платаџъ (СМ: 31). Наведени примери показују нам да Вујић експресивност постиже користећи различите морфосинтаксичке, синтаксичке и семантичке моделе.

Управо ће на тим принципима бити заснована класификација и анализа грађе. Наравно, будући да се дати критеријуми неретко укрштају, навођени примери биће експоненти једне или више класификационих група. Ексцерпирану грађу смо, сходно томе, разврстали у пет група: прву групу чине експресивни узвици и партикуле; другу, изрази зачуђености, изненађености, захвалности са лексемама враг/бог; трећу, експресивне форме обраћања; четврту, паремије и народне пословице и пету, устаљени изрази, колокације и фразеологизми.

2.1. Прва група коју бисмо издвојили јесу примери са врло ефектном употребом експресивних узвика и партикула. Према С. Ристић (1994: 146147) „партикуле [се] повезујући лексички план са планом говорних чинова, могу представити и у парадигмама које организују семантичке компоненте са илокуцијском снагом: модификовања информације; тврдње; одрицања; тражена информачије; коментара; експресивности ; конвенционалности".

Ху леле мени... бре плакаћу.. (СМ: 16)

Аяо куку леле мени! (СМ: 19)

За Бога! ... яо мое лепе косе! (СМ: 26)

Аяо куку мени! (СМ: 28)

Яо жалостиници мени леле (СМ: 15)

Яо жалости и туге мое довека! (CM: 16)

Ах! За име Божіе! (CM: 26)

Айде! Мариь сасъ пасиіомъ трагомъ! (СМ: 19)

Данась хопъ, сутра яо, ючерь сватовы а данась лежи невеста на даски мртва. Хі! $X i ! X i !(\mathrm{CM}: 58)$

\footnotetext{
${ }^{5}$ На основу значења лексеме четворка у РЈАЗУ (II: 15), a) dolium capax quatuor amphorarum, bure od četiri akova, израз дебео/-ла као четворка можемо тумачити, преко обличке матафоризације, као дебео као буре, бачва.

${ }^{6}$ Даље у тексту говорећи о експонентима експресивности и истицања код партикула, ауторка их дефинише као „показатеље комуникацијске атмосфере [који] зависно од ситуације исказују типчне позитивне или негативне реакције саговорника: задовољство, одушевљење, одобравање, подстицање, сажаљење, саосећање, солидарност, чуђење, негодовање, приговарање, упозорење, забрањивање, љутњу, нестрпљење и сл." (Исто: 151) - кроз већину таквих реакција Вујић је градио ликове и сам драмски контекст, користећи управо експресивне партикуле и узвике.
} 
Она скочи одъ жустрине на трагъ - хопь! хопь! Све выме натрагъ докле годъ ніе nyфъ! (CM: 59)

(и веома често опонашање смеха, како искреног тако и ироничног и злобног)

Употреба ових језичких средстава је јасна и очекивана и осим што доприноси експресивности, њоме се постиже и динамичност драмске радње. Врло честе елипсе у говору протагониста драме постижу се управо употребом узвика и партикула. Елиптичност и динамичност такође представљају једне од основних особина РФС. Последња два примера су структурно сложенија, а врло је ефектна и (морфо)синтаксичка конверзија узвика (данась хопь, сутра яо; докле годъ ніе пуфъ) - у њима су кондензоване очекиване (шире) структурне формације које би се могле исказати како простим конституентом (именицама, глаголима) тако и синтагмама или клаузама. Јелица Јокановић-Михајлов у свом раду о узвицима (1998: 251) такође даје примере за ову појаву, „Многи од узвика могу бити употребљени као различити реченични чланови" и наводи примере сличне оним које смо ексцерпирали код Вујића, „Немој да затвараш врата, њена мјау-мјау ме излуђују; Само што смо стигли, а он бућ! у воду" и сл.

2.2. Врло слични су, по употреби и утицају на стилску вредност текста, као и по различитој структурној сложености, примери са употребом лексеме враг и њених синонима или лексеме бог у ситуацијама када се настоји дочарати зачуђеност, изненађеност, захвалност и сл.:

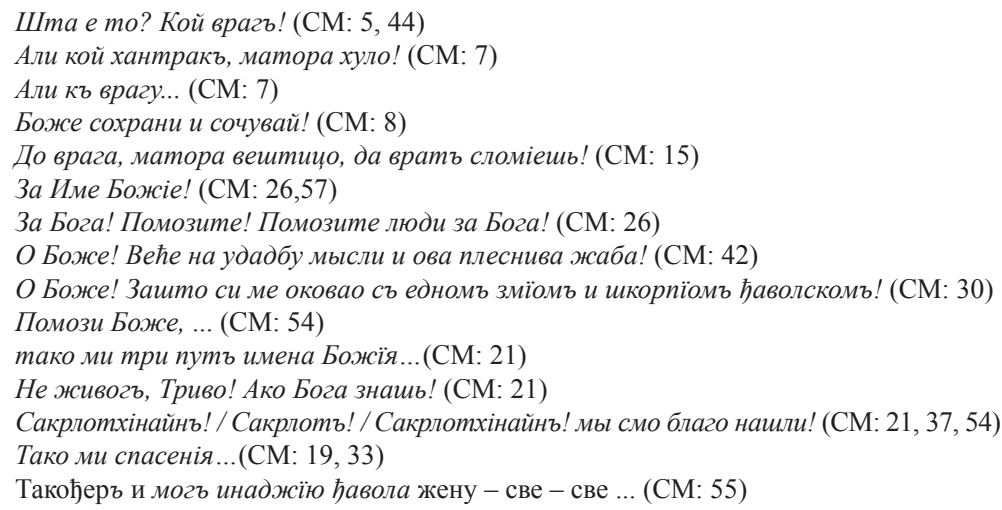

У обема овим групама налазимо и примере који својим лексичким и структурним одабиром могу бити сврстани у тзв. нижи регистар српског језика, излазећи тако из оквира норме каквом је данас схватамо. Управо на тај начин Вујић веома ефектно уводи доминантне особине разговорног стила, односно особине говорног језика (тога времена) чиме се са прагматског аспекта језик драме спушта у раван примарних реципијената, гледалаца током извођења представе. Наравно, може се говорити и о карактеризацији драмских ликова сходно заступљености оваквих пејоративних или пејоратизованих конструкција (псовке и клетве), те у односу на то да ли се у репликама одређеног лика чешће инвоцира Ђаво или бог и сл. Макрена Љутарош, као 
архетип негативног драмског карактера, очекивано, користи псовке и клетве, док Божа Мирић, ${ }^{7}$ као њен извесни антипод, користи углавном обраћање богу кроз изразе молби и захвалности.

2.3. Примери изузетне експресивне употребе различитих форми обраћања најбројнији су у Вујићевом тексту, а елементи разговорноог стила у њима су евидентни, па и инхерентни на одређени начин. Избор лексике је и у овом случају најчешће из нижег регистра и неретко и, чини се, с намером обилује различитим погрдним изразима. Структурно их можема поделити на две опште целине: експресивне вокативе и оптативне реченице, а ваља нагласити да је њихова комбинована, линеарна употреба такође веома честа.

2.3.1. Експресивност форми обраћања реализованих вокативом најчешће доноси маркирана реч - именица која представља и центар (најчешће двочлане) именичке синтагме којом су ти вокативи готово доследно исказивани.

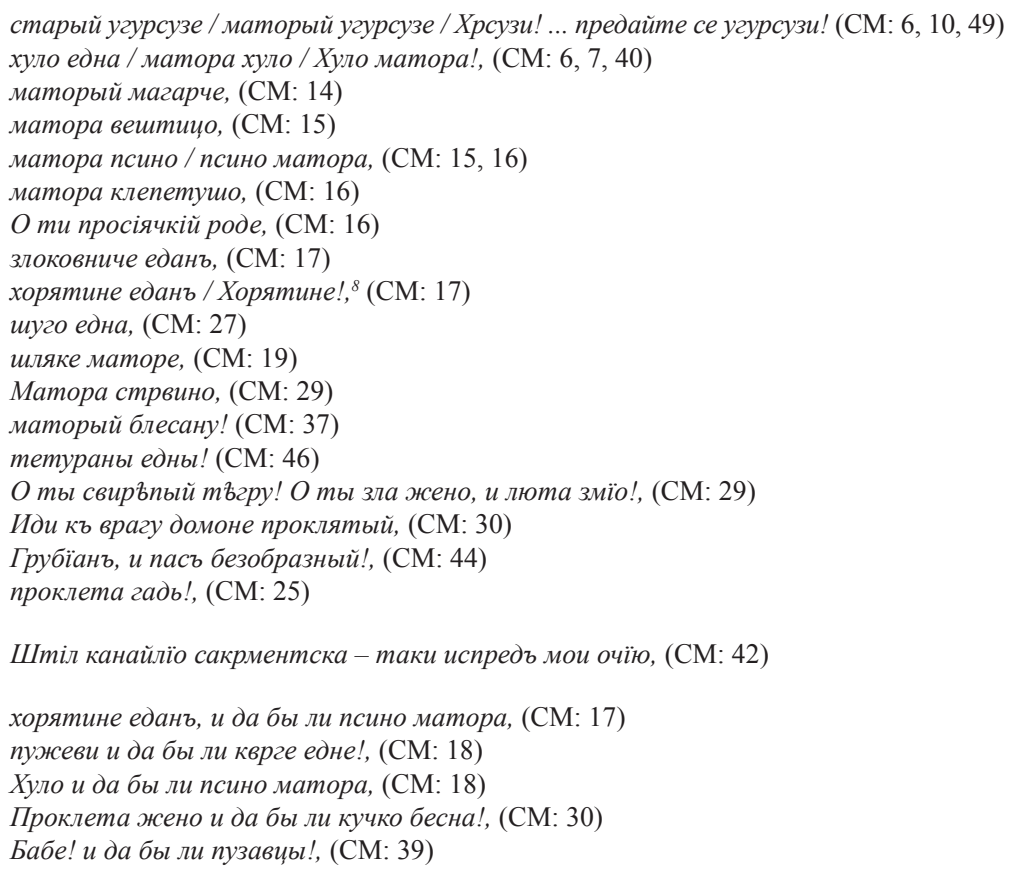

Као што видимо у првој подгрупи, примери заиста одговарају поменутом обрасцу, како структурном - двочланом синтагматском, тако и семантичком - експресивност носи именица. Једини условни изузетак био би пример O ти просіячкій роде где је атрибут експресивнији, али ова синтагма свакао

\footnotetext{
${ }^{7}$ Индикативна је и с прагматског становишта потенцијално веома интересантна анализа ономастикона драме - два поменута су вероватно најупечатљивији примери из драме, Макрена Љутарош и Божа Мирић.

${ }_{8}^{8}$ У Речнику ЈАЗУ експлицитно дефинисан као psovka čovjeku, kao ugursuz, hulja, lopov itd. (RJAZU III: 651).
} 
представља само аналитичку варијанту (експресивне) именице просјак, уз коју би се лако могао употребити неки од атрибута сличног типа као у осталим примерима (маторый, проклетылй, едань...).

Структурно - видимо да постоје различите, мање или веће, варијације. Вокативи понекад могу бити исказани и само именицом: Хорятине едан / хорятине; старый угурсузе / Хрсузи. ${ }^{9}$ Ред речи унутар синтагми може да варира: матора псино / псино матора; матора хуло / хуло матора, што може бити сигнал Вујићевог колебања између структурних клишеа народног и славеносрпског језичког регистра. Колика год била Вујићева интенција да драме (преводе драмских текстова) пише народним језиком или бар језиком разумљивим за што већи број људи (којима би представе са оваквом тематиком могле и бити намењене), ред речи је нешто што уверљиво сведочи о славеносрпском као његовом подразумеваном ауторском изразу. Такође, вокативне синтагме могу бити и уланчане $O$ mы свиръпьй mъгру! O mы зла жено, и люта змїо!. У последња два примера, Грубіянъ, и пас безобразный! и проклета гад! забележене су номинативне синтагме, али са безмало идентичним структурно-семантичким моделом.

На семантичком плану заједничка им је (као и осталим издвојеним примерима) архинегативна конотација свих израза, чија је функција с прагматског аспекта само једна - да увреди или понизи онога коме је упућена. То је остварено, како смо рекли, пажљивим и прецизним одабиром лексике, лексике из народног језика, из говореног језика тога времена, српског, односно словенског, или позајмљеница које су вероватно одавно већ биле одомаћене у језику. Негативна концептуализација одређених назива за животиње: змија, тигар, магарац, пас (кучка), пуж/пузавац крава/овца (клепетуша) - преузета из народних веровања и митологије носилац је погрдности (пејоративности) у највећем броју примера. Слично су кроз религијске и мистичне концепте у фолклористици позиционирани и примери хуља, угурсуз, вештица, стрвина, гад.

Четири примера издвојена на крају листе су структурно-семантички маркирана специфичном уланчаношћу двају експресивних вокатива у саставном напоредном односу, оптативном конструкцијом која уводи други вокатив, $\partial a$ бы ли : пужеви и да бы ли кврге едне!, Хуло и да бы ли псино матора, иляке маторе, Проклета жено и да бы ли кучко бесна!, Бабе! И да были пузавци. Потврђеност оваквих конструкција у данашњим српским дијалектима нам на још један начин потврђује да су управо овакви архетипски елементи говореног језика, односно разговорног стила, најтипичнији репрезенти народног језика Вујићевог, славеносрпског времена.

Изоловани пример, Штіл канайлїо сакрментска - таки испредъ мои очїю, такође преноси негативну и увредљиву поруку, одговара двочланој синтагматској форми, али ћемо анализу овога израза представити на другом

\footnotetext{
${ }^{9}$ Овде примећујемо и различиту фонетску адаптацију исте именице, туђице, очигледно одомаћене у народном језику.
} 
месту, када ћемо се детаљније бавити фразеолошким и паремиолошким изразима у ширем друштвено-политичком контексту.

У ексцерпираној грађи забележен је и мањи али запажен број вокативних синтагми позитивне конотације, чију структурно-семантичку особеност најчешће носе атрибути сладкый и његови синоними и центар синтагме исказан именицом у деминутиву: меденый татице (СМ: 22, 52), љубезньий татице (СМ: 23), драга шећерна Макрїце (СМ: 27). Али и примери љубезньіи друже (СМ: 32), еданъ искреный прїятелю живота могъ (СМ: 35), вы љубимыли у златне орлове претворены Слепьи Мылевы (СМ: 56), чудотворнылй Благодъю (СМ: 60), где избор лексике, њена фонетска адаптација, али и ред речи и сложеност конструкција недвосмислено упућују на виши стил, односно славеносрпски језички дискурс.

2.3.2. Како смо већ рекли, другу карактеристичну, али мање бројну групу експресивних форми обраћања чине примери оптативних реченица са препознатљивим структурним маркерима. Експлицирајући жељу као основну комуникативну функцију жељних (оптативних) реченица, те прижељкивање, клетву и благослов као њену конкретизацију, Љубомир Поповић наводи да је обележје овог типа независних реченица „употреба модалног крњег перфекта или нека + презент или $\partial a+$ презент и узвичне интонације, односно узвичника" (Станојчић/Поповић 2010: 351).

Такве конструкције се директно наслањају на већ поменуте конструкције са удвојеним вокативом повезаним оптативним да би ли, и такође припадају корпусу народног језика. Структурно потпадају под оквире (савремене) норме, али их одабир лексике често враћа у регистар пејоративних израза.

Гром да га убїе! Пасїя вера. (СМ: 19)

Громъ васъ потукао! (СМ: 26)

Кой врагъ - Што се тако дерешь? ... Хрђа те попала! ... силе те сапеле! (СМ: 27)

Хрђа вась попала, силе васъ сапеле! (СМ: 40)

Три ста врага да те носи! (СМ: 29)

Бре не лютиме - крвъ те майки сукала. (СМ: 45)

Овде опеть се могу момъ Господину младожени - крвъ га сукала - осветити. (CM: 46)

Богъ да їой души прости - на врби їой кости - на тополи ноге! (СМ: 59)

Да се тамо веће виђао Господаръ Луцїферъ на козїима ногама - частный га кресть потрео - буди Богъ съ нама и анђели Божїи (СМ: 46). ${ }^{10}$

Баш као и већина претходно наведених и анализираних примера различитих структурних модела, и за велику већину оптативних конструкција овог типа заједничка је изразита негативна конотација. Њихова комуникативна функција у свим примерима је КЛЕТВА. Чак се и у претпоследњем примеру, који почиње жељом/молбом за вечни опрост, интересантном игром речи, у којој се користи с једне стране рима прости : кости, а с друге велики симболички потенцијал фитонима врба и топола, порука заправо претвара у неку врсту клетве.

\footnotetext{
${ }^{10}$ Део фразе буди Богъ съ нама и анђели божиіи такође је оптативног карактера, с тим што је глагол исказан модалним (експресивним) императивом, синонимним конструкцији да + презент.
} 
2.4. У четвртој групи је најмањи број забележених примера, али смо их издвојили и анализирали засебно, што због видљиве Вујићеве интенције у коришћењу и модификовању пословица као симбола аутентичног народног језика, што због њиховог семантичког и структурног континуитета са наредном групом.

Вы знате ону пословицу: Една луда, начини десет другый. (CM: 7)

Ноћь никомь нїе прӥятель. (СМ: 22)

Едногъ Ђавола у кући имати и нестерпиме Кредиторе - чини и споля (и) изъ нутра pamb. (CM: 13)

Стерпвнїе е добаръ Кредиторъ, али хрђавъ платацъ...(СМ: 31)

Двадесеть година више живити, учисе вышше памети. (CM: 35)

Зашто ${ }^{11}$ добра речъ гвоздена врата отвора. (CM: 45)

Зашто самь у момъ веку чуо, да разуманъ мора попустити будали (СМ: 44).

Не можемо са сигурношћу тврдити да се сви забележени примери могу сврстати у фонд српских народних пословица, али им се паремијски карактер не може оспорити. Неке од њих можемо наћи у фонду народних пословица које је Вук забележио (добра реч гвоздена врата отвара), за неке видимо да сам Вујић (односно Тривун) сигнализира да су пословице, а за све можемо рећи да имају пословичку структуру и призвук априорне мудрости. Примери са лексемом кредитор ауторски су модификовани и актуализовани, вероватно с намером да се приближе читаоцима, тачније гледаоцима драме, ако претпоставимо да је кредитор њима познатија од народног јемаи. Коришћење оваквих, народних мудрости и данас може бити карактеристично за говорни језик, језик у народу, па и овде можемо констатовасти преплитање особина и домета разговорног стила и народног језика.

2.5. Вратимо ли се на два структурно и семантички издвајена примера у подгрупи оптативних реченица (Богъ да їой души прости - на врби їой кости - на тополи ноге!; Да се тамо веће виђао Господарь Луцїферъ на козїима ногама - частный га кресть потрео - буди Богъ съ нама и анђели Божїи), приметићемо да они представљају део веће синтаксичке целине чије значење није прозрачно, напротив, део су ширег лингвокултуролошког концепта заснованог на фразеологији и фолклористици, хришћанском и предхришћанском наслеђу, мањим или већим делом и на европском мистицизму XVIII и XIX века.

Да е зла и пакостна, како годъ Баба Луиіфер пакленогъ. (СМ: 9)

Пакъ садъ се разлютила какогодъ Асniда - цело ютро данась по двору мрмляме, псоваме, какогодъ каква бесна кучка. (СМ: 13)

Завежляй е еданъ путъ завезатъ, когъ ни Антїхрїсть веће раздрешити не може. (CM: 14)

Дотрча кокогодъ фурія паклена изъ међу ны (JВ - дидаскалија) (СМ: 19)

У оваковима случайма жене биваю, какогодъ Фуріе паклене и Aспіде едовите. (CM: 20)

Да се тамо веће виђао Господаръ Луцїферъ на козїима ногама - частный га кресть nотрео - буди Богъ съ нама и анђели Божїи (CM: 46)

\footnotetext{
${ }^{11}$ У тексту Вујићеве драме, али и уопште у Вујићевом језику и језику представника ове епохе у развоју српског језика зашто се доследно користи уместо сложеног узрочног везника зато ито.
} 

(CM: 46)

Да бы га истый Господаръ Луцїферъ у пакао са собомъ одвео, да тамо шливе суши!

Ми ћемо се начинити, како годъ вукодлацы (СМ: 46)

Дакле, Господаръ Слепый Мышь опеть и овай е посао добро ко концу привео. (CM: 51) вы љубимыл у златне орлове претворень Слепьи Мымевы (СМ: 56)

Богъ да їой души прости - на врби їой кости - на тополи ноге! (СМ: 59)

И мене може быти опеть одъ женске аждае и Луцїфера пакленогъ освободио! (СМ: 60)

Будући да су слични изрази, као што видимо, веома заступљени у драмском тексту, да њихово рашчитавање недвосмислено упућује на поменути шири друштвено-историјски контекст, да драмска радња, од заплета до расплета, веома индикативно упућује на могућност такве перцепције текста, а како и животопис Јоакима Вујића наводи на то - њихова лингвокултуролошка анализа биће предмет анализе засебног рада.

\section{3. Закључак}

Раније постављена (наведена на почетку и овог рада) хипотеза да се драмски текст може посматрати као дискурс најсличнији разговорном језику, односно народном језику одређене, у овом случају славеносрпске, епохе, те да ће се на основу специфиччних реплика карактеристичних драмских ликова моћи на известан начин реконструисати структурно-семантички потенцијал народног, односно народског језика славеносрпског времена, вишеструко је потврђена анализом грађе ексцерпиране из ове Вујићеве драме. Различити су механизми којима се аутор служи како би у текст драме увео што већи број елемената разговорног стила и на тај начин га учинио разумљивим и прихватљивим читаоцима, односно гледаоцима драме, а нама као изучаваоцима језика тога времена приближио претпостављени народни језик, који би био пандан тадашњем доминантном регистру у језику књижевности - славеносрпском језичком изразу.

Употреба експресивних везника и партикула, затим, рекли бисмо, још експресивнијих вокатива и вокативних синтагми, те различитих примера оптативних реченица са доминатном функцијом клетве, веома је фреквентна у тексту и на ефектан начин служи карактеризацији протагониста драме. Изрази којима се дочаравају ситуације зачуђености, изненађености, захвалности и сл. са лексемама Ђаво или бог такође су пример грађења драмских ликова кроз специфичан колоквијални језик, језик тзв. нижег регистра, саткан од елемената разговорног стила тога времена. Издвајају се по томе што им функција није нужно негативна, као у већини претходно издвојених примера.

Примери употребе пословица и модификованих, ауторских израза сличних њима, различитих паремиолошких израза, те веома ефектних и често непрозрачних фразеолошких израза, такође представљају Вујићеву опредељеност за увођење народног језика у језик драме, а издвајају се на синтаксичком плану доследно реченичном структуром. Експликација априорне народне мудрости кроз пословичке изразе, те увођење ширег друштвенополитичког контекста интелектуалне Еворпе тога времена опет кроз изразе 
мање или више наслоњене на народна веровања, могу се разумети као врхунац Вујићевог креативног и уметничког израза.

На макросинтаксичком плану, с друге стране, особине славеносрпског дискурса су и даље у много већој мери заступљене, него одлике претпостављеног народног језика почетка XIX века. Специфичан синтагматски и клаузални ред речи само је један од показатеља таквог стања у језику ове Вујићеве драме, претпостављамо и осталих његових драма и дела уопште.

\section{ИЗВОР}

Вујић 1809: Іоакимъ Вуичъ, Слепьй мылъ, Въ Будинь Градъ: Писмены Кралевскаго Всеучилища Венгерскаго [61 стр.] [CM]. ${ }^{12}$

\section{ЛИТЕРАТУРА}

Албијанић 1976: Александар Албијанић, Прилог познавању судбине српскословенских елемената у језику писаца из Војводине предвуковског периода, Зборник Матице српске за филологију и лингвистику, XXIX/2, $37-53$.

Албијанић 1981: Александар Албијанић, Прилог познавању деклинирања позајмљеница у неким делима Јоакима Вујића, Научни састанак слависта у Вукове дане, 7/1, 113-122.

Албијанић 1982: Александар Албијанић, Од рационализма ка романтизму: Кратак осврт на позоришни језик Јоакима Вујића, Научни састанак слависта у Вукове дане, 12, 43-53.

Албијанић 1983: Александар Албијанић, Кратак осврт на најмаркантније фонетске, морфолошке и синтаксичке особине језика Јоакима Вујића, Зборник Матице српске за филологију и лингвистику, XXVI/2, 73-79.

Албијанић 1985: Александар Албијанић, Језик белетристике Јоакима Вујића, Научни састанак слависта у Вукове дане, 14/3, 69-78.

Албијанић 1986: Александар Албијанић, Језик нештампаних драма Јоакима Вујића, Зборник Матице српске за филологију и лингвистику, XXIX/1, $113-125$.

Албијанић 2010: Александар Албијанић, Прилози о српском предвуковском књижевном језику, Нови Сад: Матица Српска - Београд: ЗУНС; Вукова задужбина.

Белић 1999: Александар Белић, Историја српског језика, Изабрана дела Александра Белића, т. 7, Београд: Завод за уџбенике и наставна средства.

\footnotetext{
12 (http://digital.bms.rs/ebiblioteka/pageFlip/reader/index.php?type=publications\&id=1299\&m=2 \#page/5/mode/1up)
} 
Белић 2000: Александар Белић, О различитим питањима савременог језика, Изабрана дела Александра Белића, т. 13, Београд: Завод за уџбенике и наставна средства.

Даничић 1871: Gjuro Daničić (ur.), Poslovice, Zagreb: U knjižarnici fr. Župana (Albrechta i Fiedlera).

Ђорђевић 1898: Пера П. Ђорђевић, О реду речи у српском језику, (приступна академска беседа), Глас Српске краљевске академије, LIII, 167-231.

Ивић 1991: Павле Ивић, Доситејевски књижевни језик између славеносрпског и вуковског, Научни састанак слависта у Вукове дане, 19/2, 5-14.

Јовановић 2013: Јелена Јовановић, Лингвистички и стилистички аспекти проучавања реченице, Београд: Научно друштво за неговање и проучавање српског језика.

Јокановић Михајлов 1998: Јелица Јокановић-Михајлов, Узвици као врста речи, Научни састанак слависта у Вукове дане, 27/2, 247-252.

Кликовац 2008: Душка Кликовац, Језик и моћ, Београд: Библиотека XX век - Круг.

Ковачевић 1998: Милош Ковачевић, Синтакса сложене реченице у српском језику, Београд: Рашка школа; Србиње: Српско просвјетно и културно друштво Просвјета.

Ковачевић 2015: Милош Ковачевић, Кроз синтагме и реченице, Београд: Јасен.

Ковачевић ${ }^{42015: ~ М и л о ш ~ К о в а ч е в и ћ, ~ С т и л и с т и к а ~ и ~ г р а м а т и к а ~ с т и л с к и х ~}$ фигура, Београд: Јасен.

Ковачек и др. 1988: Божидар Ковачек, Петар Марјановић, Душан Михаиловић, Душан Рњак, О театарском делу Јоакима Вујића, Нови Сад: Матица српска, Одељење за сценске уметности и музику.

Матић 2016: Томислав Матић, Прагматска анализа индивидуалних фразеолошких израза у драмама Александра Поповића, Научни састанак слависта у Вукове дане, 45/1, Београд, 407-418.

Милановић 2013: Александар Милановић, Језик весма полезан, Београд: Друштво за српски језик и књижевност Србије.

Милановић 2014: Александар Милановић, Језик Јована Суботића, Београд: Филолошки факултет.

Младеновић 1989: Александар Младеновић, Славеносрпски језик, Нови Сад: Књижевна заједница Новог Сада.

Мршевић Радовић 2 2014: Драгана Мршевић-Радовић, Фразеологија и наџионална култура, Београд: Друштво за српски језик и књижевност.

Пипер и др. 2005: Предраг Пипер, Ивана Антонић, Владислава Ружић, Срето Танасић, Људмила Поповић, Бранко Тошовић, Синтакса савременог српског језика, Проста реченища, Београд: Институт за српски језик САНУ, Београдска књига - Нови Сад: Матица српска.

PJA3У 1880-1976: Rječnik hrvatskoga ili srpskoga jezika Jugoslavenske akademije znanosti i umjetnosti, I-XXIII, Zagreb: JAZU.

PМC 1967-1976: Речник српскохрватског књижевног језика, I-VI, Нови Сад: Матица српска. 
РСАНУ 1959-2017: Речник српскохрватског књижевног и народног језика, књига I-XX, Београд: Институт за српски језик САНУ.

Ристић 1994: Стана Ристић, Илокуцијски аспекти употребе партикула, Јужнословенски филолог, L, 145-154.

Симић 1991: Радоје Симић, О нашем књижевном језику, Никшић: НИП „Универзитетска ријеч”.

Станојчић/Поповић ${ }^{82000: ~ Ж и в о ј и н ~ С т а н о ј ч и ћ, ~ Љ у б о м и р ~ П о п о в и ћ, ~ Г р а-~}$ матика српскога језика, Уибеник за I, II, III и IV разред средње школе, Београд: Завод за уџбенике и наставна средства.

Стевановић 1989: Михаило Стевановић, Савремени српскохрватски језик II, Синтакса, Београд: Народна књига.

Стијовић и др. 2019: Рада Стијовић, Ивана Лазић Коњик, Марина Спасојевић, Узвици у савременом српском језику: класификација и лексикографска обрада, Јужнословенски филолог, LXXV, 37-61.

Тошовић 2002: Бранко Тошовић, Функиионални стилови, Београд: Београдска књига.

Ујес 1985: Алојз Ујес, Позоришно стварање и трајање Јоакима Вујића 1805-1985, Крагујевац: Одбор за обележавање 150-годишњице првог српског позоришта.

Ујес 1988: Алојз Ујес, Позоришно стваралаштво Јоакима Вујића, (поводом 175-годишњице прве позоришне представе у Срба 24. августа 1813), Београд: САНУ.

Tomislav M. Matić

\section{ELEMENTS OF CONVERSATIONAL STYLE AS REPRESENTS OF THE VERNACULAR LANGUAGE OF THE EPOCH IN JOAKIM VUJIĆ'S PLAYS}

Summary

In this paper, by structural, structural-semantic and pragmatic analysis of specific expressions with different elements of conversational style extracted from the Joakim Vujic's play Slepi miš, we find that the language of the play abounds in the elements of the assumed spoken, vernacular language of the epoch (the late 18th and the first half of the 19th century), and that the hypothesis that in replicas of the protagonists of the play can first be reconstructed the elements of the vernacular language as counterbalance to the dominant literary (written) expression of the epoch - Slavonic Serbian language, has been repeatedly confirmed.

Key words: conversation style, expressiveness, non-normativeness, appelative forms, vocative case, optative constructions, Slavonic Serbian language, vernaculare language. 